\title{
Emticicia oligotrophica gen. nov., sp. nov., a new member of the family 'Flexibacteraceae', phylum Bacteroidetes
}

\author{
Correspondence \\ T. Chakrabarti \\ tapan@imtech.res.in
}

\section{P. Saha and T. Chakrabarti}

\author{
Microbial Type Culture Collection and Gene Bank (MTCC), Institute of Microbial Technology, \\ Sector 39A, Chandigarh 160 036, India
}

\begin{abstract}
An aquatic bacterium, strain GPTSA $100-15^{\top}$, was isolated on nutritionally poor medium TSBA100 (tryptic soy broth diluted 100 times and solidified with $1.5 \%$ agarose) and characterized using a polyphasic approach. The isolate was unable to grow on commonly used nutritionally rich media such as tryptic soy agar, nutrient agar and Luria-Bertani agar. Phylogenetic analysis based on 16S rRNA gene sequences revealed that the isolate was affiliated with the family 'Flexibacteraceae' in the phylum Bacteroidetes. Phylogenetically, it showed closest similarity (94.0\%) with an uncultured bacterial clone, HP1A92, detected in a sludge microbial community. Among the culturable bacteria, the isolate had highest $16 \mathrm{~S}$ rRNA gene sequence similarity with Leadbetterella byssophila $4 \mathrm{M}^{1} 5^{\top}(87 \cdot 8 \%)$. Sequence similarities with other members of the phylum Bacteroidetes were less than $85 \%$. The fatty acid profile of the isolate grown on TSBA100 indicated that the major fatty acid was iso- $\mathrm{C}_{15: 0}$, which is also present in many members of the family 'Flexibacteraceae'. Cells of strain GPTSA $100-15^{\top}$ are Gram-negative, strictly aerobic rods. The DNA G $+C$ content of the isolate is $36.9 \mathrm{~mol} \%$. Results of phenotypic, chemotaxonomic and phylogenetic analyses clearly indicate that strain GPTSA100-15 ${ }^{\top}$ represents a new genus within the family 'Flexibacteraceae'; the name Emticicia gen. nov. is proposed for the genus, with Emticicia oligotrophica sp. nov. as the type species. The type strain of Emticicia oligotrophica is GPTSA $100-15^{\top}\left(=\operatorname{MTCC} 6937^{\top}=\right.$ DSM $\left.17448^{\top}\right)$.
\end{abstract}

Members of the phylum Bacteroidetes (Ludwig \& Klenk, 2001; Garrity \& Holt, 2001) are widely distributed in nature, particularly in aquatic systems (Glöckner et al., 1999; Kirchman, 2002; Yoon et al., 2005), and are known to play important roles in biogeochemical cycling and degradation of complex biopolymers like cellulose, chitin (Cottrell \& Kirchman, 2000) and agar (Nedashkovskaya et al., 2003). Recently, a member of this phylum associated with decay of a planktonic bloom, Aquiflexum balticum, was described (Brettar et al., 2004). Over the past few years taxonomic reclassification of many taxa has been reported (Bernardet et al., 1996; Bowman, 2000). In the second edition of Bergey's Manual of Systematic Bacteriology, the phylum Bacteroidetes includes three classes, 'Bacteroides', Flavobacteria and 'Sphingobacteria'. The class 'Sphingobacteria' includes five families, of which 'Flexibacteraceae' is the largest, represented by ten genera (Garrity \& Holt, 2001). Since then, a few more

\footnotetext{
Abbreviation: CMC, carboxymethylcellulose.
}

The GenBank/EMBL/DDBJ accession number for the $16 \mathrm{~S}$ rRNA gene sequence of strain GPTSA100-15 $15^{\top}$ is AY904352.

An extended phylogenetic tree based on 16S rRNA gene sequences of members of the phylum Bacteroidetes is available as supplementary material in IJSEM Online. genera have been described. In this paper, taxonomic characterization is described of a novel bacterial strain belonging to the family 'Flexibacteraceae', GPTSA100-15 ${ }^{\mathrm{T}}$, isolated from Assam, India.

Strain GPTSA100-15 ${ }^{\mathrm{T}}$ was isolated on TSBA100 medium (normal strength tryptic soy broth diluted 100 times and solidified with $1.5 \%$, w/v, agarose) by dilution plating and incubating the plates at $37^{\circ} \mathrm{C}$. Since the strain could not grow on commonly used nutritionally rich media, its ability to grow on media of different compositions was checked. Media used in this study are as follows (compositions expressed in \%, w/v): TSBA (tryptic soy broth, 3; agar, $1 \cdot 5$ ), YEA (yeast extract, $0 \cdot 5 ; \mathrm{CaCl}_{2}, 0 \cdot 1$; agar, $1 \cdot 5 ; \mathrm{pH} 7 \cdot 2$ ), modified R2A (MR2A) agar (Casamino acids, $0 \cdot 025$; yeast extract, 0.05; peptone, 0.075; glucose, 0.05; soluble starch, $0 \cdot 05 ; \mathrm{K}_{2} \mathrm{HPO}_{4}, 0 \cdot 03 ; \mathrm{MgSO}_{4} .7 \mathrm{H}_{2} \mathrm{O}, 0 \cdot 0024$; sodium pyruvate, 0.03; agar, 1.5; pH 7.2), R3A agar, MHA (MuellerHinton agar), TSIA (triple-sugar iron agar), MAC (MacConkey agar), NA (nutrient agar), NB (nutrient broth), NA-NaCl (NA devoid of $\mathrm{NaCl}$ ), CA (cytophaga agar), LY agar [1 mM phosphate buffer, $\mathrm{pH} 7 \cdot 0$; yeast extract, $0 \cdot 01 ; \quad\left(\mathrm{NH}_{4}\right)_{2} \mathrm{SO}_{4}, 0 \cdot 1 ; \quad \mathrm{MgSO}_{4} .7 \mathrm{H}_{2} \mathrm{O}, 0 \cdot 05$; $\mathrm{CaCl}_{2} \cdot 2 \mathrm{H}_{2} \mathrm{O}, 0 \cdot 005$; standard trace elements; agar, $\left.1 \cdot 5\right]$, LBA (Luria-Bertani agar), ZMA (ZoBell marine agar) and 
PCA (plate count agar). Media were made nutritionally poor by diluting these media with distilled water and solidifying them with $1.5 \%$ agarose. Dilutions are indicated by the abbreviated name of the medium followed by 100 . For acid production, modified MR2A broth (MR2A without starch, glucose and sodium pyruvate) supplemented with $0.5 \%$ of the desired carbon source and phenol red (as $\mathrm{pH}$ indicator) was used; for methyl red/Voges-Proskauer tests, the same basal medium as above was used, supplemented with $0.5 \%$ glucose. Sole carbon source utilization medium ( $\mathrm{pH} 7 \cdot 2)$ contained the following, supplemented with $1 \%$ carbon source (\%): $\left(\mathrm{NH}_{4}\right)_{2} \mathrm{SO}_{4}, 0 \cdot 2 ; \mathrm{K}_{2} \mathrm{HPO}_{4}$, $0 \cdot 024 ; \mathrm{MgSO}_{4} .7 \mathrm{H}_{2} \mathrm{O}, 0 \cdot 024 ; \mathrm{KCl}, 0 \cdot 01$; yeast extract, $0 \cdot 01$; agarose, $1 \cdot 5$.

Tests for phenotypic properties were carried out by standard methods (Smibert \& Krieg, 1994; Murray et al., 1994; Powers, 1995; Cowan \& Steel, 1965). Growth at different temperatures, $\mathrm{pH}$ and $\mathrm{NaCl}$ concentrations was checked on basal TSBA100 medium. Growth on various media (TSBA, CA, LY agar, YEA, R2A agar, R3A agar, MR2A agar, MHA, TSIA, NA, NA-NaCl, ZMA, PCA, NA100, LBA100, ZMA100, MAC100, MHA100 and TSI100) was also checked at $37^{\circ} \mathrm{C}$. Determination of gliding motility was made essentially according to Bowman (2000) but on MR2A agar. Flexirubin pigment production was determined by exposing bacterial cell mass to $20 \%(\mathrm{w} / \mathrm{v}) \mathrm{KOH}$ solution according to Reichenbach (1989). All biochemical tests were done at $37^{\circ} \mathrm{C}$. Phenotypic properties of the strain are given in the genus and species descriptions. Hydrolysis of cellulose (filter paper) and chitin was tested by overlaying the respective substrates on MR2A agar solidified with $1 \cdot 2 \%$ agar. Hydrolysis of carboxymethylcellulose (CMC) was checked on modified MR2A agar supplemented with $0.5 \%(\mathrm{w} / \mathrm{v})$ CMC (Sigma) for up to 7 days. Plates were flooded with $0 \cdot 2 \%$ aqueous Congo red dye solution followed by removal of extra dye and flooding the plate with $1 \mathrm{M} \mathrm{NaCl}$ solution. A clear zone around bacterial growth indicated positive hydrolysis. For determining hydrolysis of various other substrates, MR2A agar supplemented with substrates at concentrations normally recommended in standard methods (Smibert \& Krieg, 1994; Cowan \& Steel, 1965) was used. Sensitivity to antibiotics was tested on MR2A agar using antibiotic susceptibility discs (Hi-Media) of ampicillin $(10 \mu \mathrm{g})$, bacitracin $(8 \mathrm{U})$, chloramphenicol $(30 \mu \mathrm{g})$, erythromycin $(15 \mu \mathrm{g})$, gentamicin $(10 \mu \mathrm{g})$, kanamycin $(30 \mu \mathrm{g})$, lincomycin $(2 \mu \mathrm{g})$, neomycin $(30 \mu \mathrm{g})$, novobiocin $(30 \mu \mathrm{g})$, norfloxacin $(10 \mu \mathrm{g})$, penicillin $\mathrm{G}(10 \mathrm{U})$, polymyxin $\mathrm{B}(300 \mathrm{U})$, rifampicin $(2 \mu \mathrm{g})$, streptomycin $(10 \mu \mathrm{g})$, sulfasomidine $(300 \mu \mathrm{g})$ and tetracycline $(3 \mu \mathrm{g})$.

For cellular fatty acid analysis, the isolate was grown on TSBA 100 medium at $30^{\circ} \mathrm{C}$ for $48 \mathrm{~h}$. Extraction and analysis of cellular fatty acids were done according to procedures of the SHERLOCK Microbial Identification system (MIDI), as described previously (Pandey et al., 2002). Major fatty acids were iso- $\mathrm{C}_{15: 0}(42 \cdot 9 \%)$, iso- $\mathrm{C}_{17: 0} 3-\mathrm{OH}$
$(12 \cdot 5 \%)$, anteiso- $\mathrm{C}_{15: 0}(12 \cdot 2 \%)$, summed feature 3 (iso$\mathrm{C}_{15: 0} 2-\mathrm{OH}$ and/or $\left.\mathrm{C}_{16: 1} \omega 7 c, 11 \cdot 3 \%\right)$, iso- $\mathrm{C}_{15: 0} 3-\mathrm{OH}$ $(5 \cdot 6 \%), \mathrm{C}_{15: 1} \omega 6 c(5 \cdot 5 \%)$ and $\mathrm{C}_{16: 1} \omega 5 c(3 \cdot 8 \%)$. The presence of iso- $\mathrm{C}_{15: 0}$ fatty acid has been reported for many members of the family 'Flexibacteraceae'. Genomic DNA of GPTSA $100-15^{\mathrm{T}}$ was isolated according to Marmur (Johnson, 1994). The $\mathrm{G}+\mathrm{C}$ content of genomic DNA was determined spectrophotometrically as described previously (Saha et al., 2005). Genomic G + C content of strain GPTSA $100-15^{\mathrm{T}}$ was $36 \cdot 9 \mathrm{~mol} \%$. Amplification of the $16 \mathrm{~S}$ rRNA gene from the isolate was done using primers $27 \mathrm{f} \mathrm{(} 5^{\prime}$ AGAGTTTGATCCTGGCTCAG- ${ }^{\prime}$ ) and 1492r ( $5^{\prime}$-TACGGYTACCTTGTTACGACTT-3'). Amplification, purification of the amplicon and sequencing of the 16S rRNA gene were done as described by Pandey et al. (2002). A nearly complete (1385 nt continuous stretch) 16S rRNA gene sequence of the isolate was used to search for similar sequences from GenBank and the RDP. Various online sequence analysis tools available from RDP release 9.1 (http://rdp.cme.msu.edu/index.jsp, RDP analysis tools) were also used to get an idea of the systematic position of the strain. Sequence analysis revealed that GPTSA100$15^{\mathrm{T}}$ is a member of the phylum Bacteroidetes showing closest similarity $(94 \cdot 0 \%)$ with an uncultured bacterial clone, HP1A92, which was a representative sequence of a sludge microbial community (McMahon et al., 2002). Among the culturable bacteria, it showed closest similarity to Leadbetterella byssophila $4 \mathrm{M} 15^{\mathrm{T}}(87 \cdot 8 \%)$. Sequence similarities with other members of the phylum Bacteroidetes were less than $85 \%$. Since $16 \mathrm{~S}$ rRNA gene sequence similarity of $95 \%$ or less is generally regarded as a borderline for describing a new genus (Ludwig et al., 1998), low sequence similarity $(87 \cdot 8 \%$ and less) with cultured bacterial relatives clearly indicated that GPTSA100-15 $5^{\mathrm{T}}$ should be treated as a representative of a new genus. For determination of the phylogenetic position of GPTSA100-15 ${ }^{\mathrm{T}}$, the sequence of its closest uncultured bacterial relative as well as 73 strains from different representative families within the phylum Bacteroidetes were retrieved (RDP analysis tools Hierarchy Browser; NCBI taxonomy browser), aligned by the program CLUSTAL_X (Thompson et al., 1997) and edited manually. Aligned sequences were analysed by the TREECON software package (Van de Peer \& De Wachter, 1997). Neighbourjoining (NJ) analysis (Saitou \& Nei, 1987) with the correction of Jukes \& Cantor (1969) was carried out with Bacillus subtilis as an outgroup. The stability of the tree was estimated by bootstrap analysis of 1000 replications. The analyses indicated phylogenetic positioning of the strain in the family 'Flexibacteraceae' (see Supplementary Fig. S1 in IJSEM Online). Using the parameters and software mentioned above and 16S rRNA gene sequences from 22 representative culturable genera of the family 'Flexibacteraceae' and the sequence of uncultured bacterial clone HP1A92, an NJ tree was constructed to reveal the position of strain GPTSA100-15 $5^{\mathrm{T}}$ within this family. A phylogenetic tree was also constructed by the maximumparsimony method using DNAPARS from the PHYLIP package (Felsenstein, 1993). Irrespective of the tree-generating 
method used, strain GPTSA100- $15^{\mathrm{T}}$ always formed a clade with the uncultured bacterial clone HP1A92 that was separate from the Leadbetterella clade within the family 'Flexibacteraceae' with a very high bootstrap value (Fig. 1). Strain GPTSA $100-15^{\mathrm{T}}$ could also be differentiated from its closest relatives on the basis of phenotypic properties and $\mathrm{G}+\mathrm{C}$ content (Table 1). Moreover, the similarity of strain GPTSA $100-15^{\mathrm{T}}$ with its closest cultured bacterial relatives at the $16 \mathrm{~S}$ rRNA gene sequence level was low enough $(87 \cdot 8 \%$ and less) to justify it as a member of a new genus. Thus, on the basis of polyphasic characterization, it is concluded that GPTSA $100-15^{\mathrm{T}}$ represents a novel species in a new genus for which the name Emticicia oligotrophica gen. nov., sp. nov. is proposed.

\section{Description of Emticicia gen. nov.}

Emticicia (Em.ti.ci'cia. N.L. fem. n. Emticicia arbitrarily formed from the acronym MTCC for Microbial Type Culture Collection and Gene Bank, where this investigation was carried out).

Gram-negative, strictly aerobic, non-motile rods occurring mostly singly, sometimes in pairs. Positive for oxidase and nitrate reduction; weakly positive for catalase. Major wholecell fatty acids are iso- $\mathrm{C}_{15: 0}$, iso- $\mathrm{C}_{17: 0} 3-\mathrm{OH}$, anteiso- $\mathrm{C}_{15: 0}$, summed feature 3 (iso- $\mathrm{C}_{15}$ : $2-\mathrm{OH}$ and/or $\mathrm{C}_{16: 1} \omega 7 \mathrm{c}$ ), iso$\mathrm{C}_{15: 0} 3-\mathrm{OH}$ and $\mathrm{C}_{15: 1} \omega 6 c$. On the basis of $16 \mathrm{~S}$ rRNA gene sequence analysis, the genus is affiliated to the family 'Flexibacteraceae' in the phylum Bacteroidetes. The type species is Emticicia oligotrophica.

\section{Description of Emticicia oligotrophica sp. nov.}

Emticicia oligotrophica (o.li.go.tro' phi.ca. Gr. adj. oligos few; Gr. adj. trophikos nursing, tending or feeding; N.L. fem. adj. oligotrophica eating little, referring to a bacterium living on low-nutrient media).

In addition to properties described for the genus, the species has the following characteristics. Colonies on TSBA100 medium after 2 days growth at $37^{\circ} \mathrm{C}$ appear round, mucoid, light pink and convex with almost entire margins; with prolonged incubation, the colony colour deepens, it produces slime and appears glistening. Cells are usually 2-5 $\mu \mathrm{m}$ long and $0 \cdot 3-0 \cdot 4 \mu \mathrm{m}$ wide; in an aged culture, some cells may be longer. No gliding motility observed. No flexirubin pigment detected. Grows at $15-42{ }^{\circ} \mathrm{C}$ and pH 5•0-11.0; cannot grow in $1 \% \mathrm{NaCl}$. Positive for methyl red, but negative for Voges-Proskauer test. Cannot grow on most of the common nutritionally rich culture media (e.g. TSBA, NA, LBA, PCA, MHA, TSIA and ZMA), but grows on R2A, R3A and 100-fold dilutions of all these media. It can hydrolyse gelatin, starch, Tween 60 and urea, but not casein, ONPG, hypoxanthine, chitin, cellulose (CMC or filter paper), xylan, tyrosine or Tween 20, 40

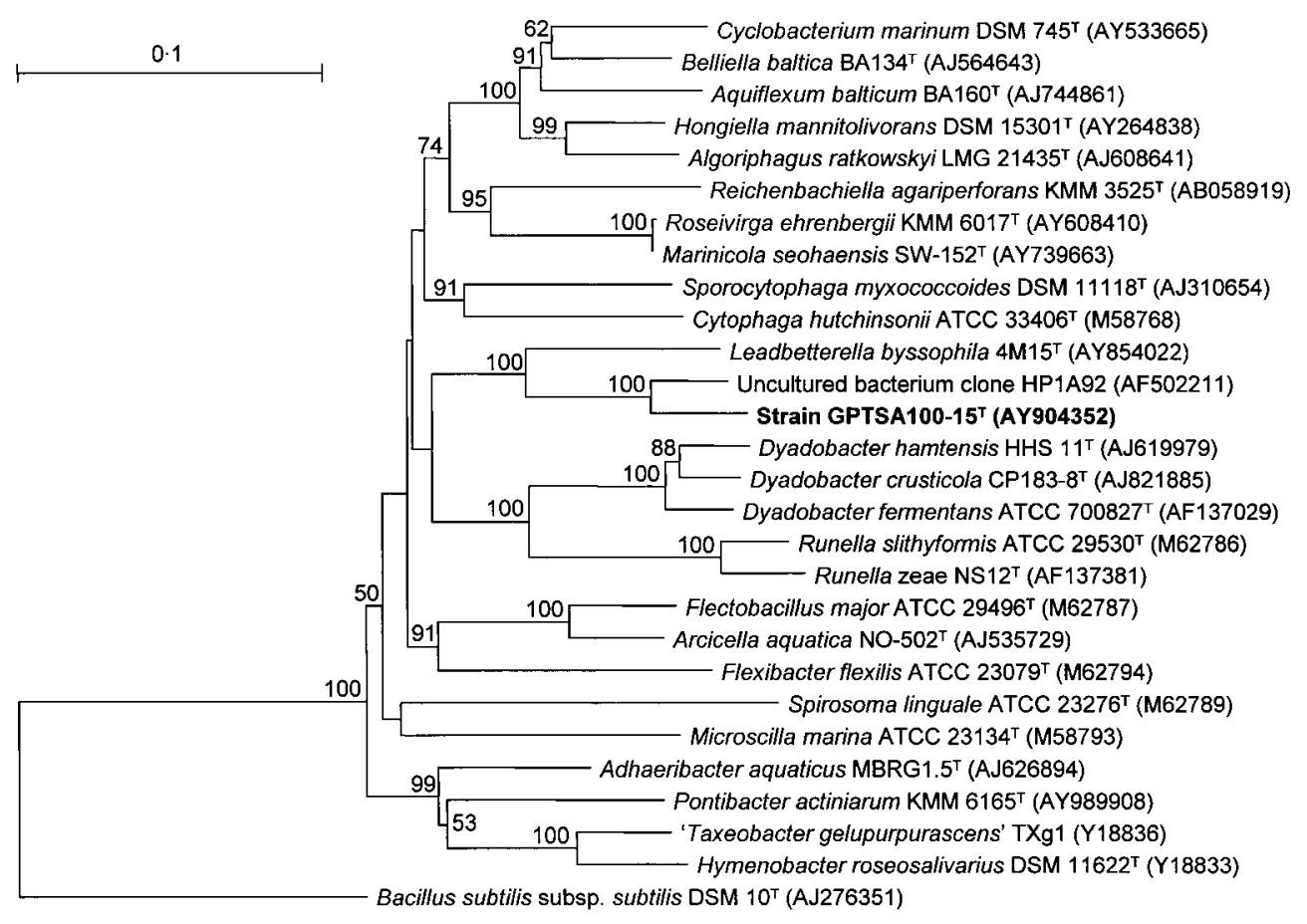

Fig. 1. Neighbour-joining phylogenetic tree based on 16S rRNA gene sequence analysis showing the relative position of GPTSA $100-15^{\top}$ among various representative members of the family 'Flexibacteraceae'. Bootstrap values greater than $50 \%$ (percentages of 1000 replications) are shown at nodes. Bar, $0 \cdot 1$ substitutions per site. The sequence from Bacillus subtilis subsp. subtilis DSM $10^{\top}$ was used as an outgroup. 
Table 1. Differential characteristics of GPTSA $100-15^{\top}$ and some of its close phylogenetic relatives

Taxa: 1, strain GPTSA100-15 $;$; 2, Leadbetterella byssophila (data from Weon et al., 2005); 3, Runella slithyformis (Larkin \& Borral, 1984; Chelius \& Triplett, 2000); 4, Runella zeae (Chelius \& Triplett, 2000; Chelius et al., 2002); 5, Dyadobacter fermentans (Chelius \& Triplett, 2000; Chaturvedi et al., 2005); 6, Dyadobacter crusticola (Reddy \& Garcia-Pichel, 2005; Chaturvedi et al., 2005); 7, Dyadobacter hamtensis (Chaturvedi et al., 2005). +, Positive; $\mathrm{w}+$, weakly positive; -, negative; v, variable; SL, slight; ND, data not available; NM, not mentioned.

\begin{tabular}{|c|c|c|c|c|c|c|c|}
\hline Characteristic & 1 & 2 & 3 & 4 & 5 & 6 & 7 \\
\hline Colony colour ${ }^{*}$ & LP & $\mathrm{O}$ & s & s & Y & Y & LY \\
\hline Flexirubin & - & + & - & - & + & + & + \\
\hline Growth on TSA & - & + & - & $\mathrm{ND}$ & $\mathrm{ND}$ & + & ND \\
\hline $\mathrm{pH}$ range for growth & $5 \cdot 0-11 \cdot 0$ & $6 \cdot 0-8 \cdot 0$ & ND & ND & $\mathrm{ND}$ & $6 \cdot 0-8 \cdot 0$ & $6 \cdot 0-8 \cdot 0$ \\
\hline Nitrate reduction to nitrite & + & - & - & - & - & - & - \\
\hline Methyl red test & $\mathrm{w}+$ & ND & - & ND & $\mathrm{ND}$ & - & - \\
\hline $\mathrm{NaCl}$ tolerance $(\%, \mathrm{w} / \mathrm{v})$ & $<1$ & 1 but not 3 & $<1 \cdot 5$ & $<1 \cdot 5$ & $1 \cdot 5$ & 1 & $11 \cdot 6$ \\
\hline Amylase & + & + & SL & - & - & - & - \\
\hline Gelatinase & + & + & - & - & - & - & - \\
\hline Urease & + & - & - & $\mathrm{ND}$ & $\mathrm{ND}$ & - & - \\
\hline Degradation of tyrosine & - & + & $\mathrm{ND}$ & $\mathrm{ND}$ & $\mathrm{ND}$ & ND & ND \\
\hline \multicolumn{8}{|l|}{ Acid production from: } \\
\hline Sucrose & $\mathrm{w}+$ & ND & + & + & + & - & - \\
\hline Ribose & - & ND & - & - & + & - & - \\
\hline Galactose & $\mathrm{w}+$ & $+/ \mathrm{w}+$ & $\mathrm{V}$ & $\mathrm{ND}$ & $\mathrm{ND}$ & - & - \\
\hline Fructose & - & ND & - & ND & - & + & - \\
\hline Maltose & $\mathrm{w}+$ & $+/ \mathrm{w}+$ & + & ND & + & - & - \\
\hline Isolation source $\dagger$ & ws & CWC & FW & SSS & SSS & BSC & GW \\
\hline DNA G $+C$ content $(\mathrm{mol} \%)$ & $36 \cdot 9$ & 33 & 49 & 49 & 48 & 48 & 49 \\
\hline Presence of anteiso- $\mathrm{C}_{15: 0}(\%)$ & $+(12 \cdot 2)$ & $+(0 \cdot 4)$ & $+(4 \cdot 3)$ & $+(4 \cdot 0)$ & $\mathrm{NM}$ & NM & NM \\
\hline
\end{tabular}

${ }^{\star}$ LP, Light pink; LY, light yellow; O, orange; S, salmon; Y, yellow.

$\dagger \mathrm{BSC}$, Biological soil crust sample; CWC, cotton waste compost; FW, freshwater; GW, glacial water; sss, surface-sterilized stem of Zea mays; ws, warm spring water.

or 80. Can utilize D-cellobiose, D-lactose, D-melezitose, Draffinose and arbutin; weakly utilizes L-arabinose, L-arabitol, D-amygdalin, D-fructose, D-galactose, D-glucose, glycerol, myo-inositol, D-melibiose and sucrose as sole carbon sources. Cannot utilize adonitol, dulcitol, D-mannitol, D-sorbitol, L-sorbose or xylitol as sole carbon sources. Produces acids from arbutin, D-cellobiose, D-glucose, D-lactose, methyl $\alpha$-D-glucoside, salicin, D-trehalose and D-xylose and weakly from D-galactose, D-maltose, D-mannose, D-melibiose, D-melezitose and sucrose, but not from adonitol, D-amygdalin, L-arabinose, L-arabitol, dulcitol, aesculin, erythritol, D- or L-fucose, D-fructose, glycerol, glycogen, myo-inositol, inulin, 2-ketogluconate, D-mannitol, D-raffinose, D-ribose, D-sorbitol, L-sorbose or xylitol. Sensitive to ampicillin, bacitracin, chloramphenicol, erythromycin, gentamicin, kanamycin, lincomycin, neomycin, novobiocin, norfloxacin, penicillin $\mathrm{G}$, polymyxin $\mathrm{B}$, rifampicin, streptomycin, sulfasomidine and tetracycline. The genomic DNA $\mathrm{G}+\mathrm{C}$ content of the type strain is $36 \cdot 9 \mathrm{~mol} \%$.

The type strain is GPTSA100- $15^{\mathrm{T}}\left(=\right.$ MTCC $6937^{\mathrm{T}}=\mathrm{DSM}$ $17448^{\mathrm{T}}$ ), isolated from a warm spring water sample from Assam, India.

\section{Acknowledgements}

We are grateful to Dr K. Ganesan for his help in DNA sequencing and Professor H.G. Trüper and Dr J. Euzéby for their help with etymology. We acknowledge with thanks help provided by Dr T.C. Bora, Biotechnology Division, Regional Research Laboratory, Jorhat, Assam, in collection of the sample. We also thank Dr A. Mondal, Dr G. S. Prasad, Mr S. Mayilraj, Dr K. Suresh, Mr S. Krishnamurthi and $\mathrm{Mr}$ A. Bhattacharya for useful discussions. Financial assistance from DBT, Government of India and CSIR is duly acknowledged. P. S. is the recipient of a CSIR fellowship. This is IMTECH communication number 043/2005.

\section{References}

Bernardet, J.-F., Segers, P., Vancanneyt, M., Berthe, F., Kersters, K. \& Vandamme, P. (1996). Cutting a Gordian knot: emended classification and description of the genus Flavobacterium, emended description of the family Flavobacteriaceae, and proposal of Flavobacterium hydatis nom. nov. (basonym, Cytophaga aquatilis Strohl and Tait 1978). Int J Syst Bacteriol 46, 128-148.

Bowman, J. P. (2000). Description of Cellulophaga algicola sp. nov., isolated from the surfaces of Antarctic algae, and reclassification of Cytophaga uliginosa (ZoBell and Upham 1944) Reichenbach 1989 as Cellulophaga uliginosa comb. nov. Int J Syst Evol Microbiol 50, 1861-1868. 
Brettar, I., Christen, R. \& Höfle, M. G. (2004). Aquiflexum balticum gen. nov., sp. nov., a novel marine bacterium of the CytophagaFlavobacterium-Bacteroides group isolated from surface water of the central Baltic Sea. Int J Syst Evol Microbiol 54, 2335-2341.

Chaturvedi, P., Reddy, G. S. N. \& Shivaji, S. (2005). Dyadobacter hamtensis sp. nov., from Hamta glacier, located in the Himalayas, India. Int J Syst Evol Microbiol 55, 2113-2117.

Chelius, M. K. \& Triplett, E. W. (2000). Dyadobacter fermentans gen. nov., sp. nov., a novel Gram-negative bacterium isolated from surface-sterilized Zea mays stems. Int J Syst Evol Microbiol 50, 751-758.

Chelius, M. K., Henn, J. A. \& Triplett, E. W. (2002). Runella zeae sp. nov., a novel Gram-negative bacterium from the stems of surface-sterilized Zea mays. Int J Syst Evol Microbiol 52, 2061-2063.

Cottrell, M. T. \& Kirchman, D. L. (2000). Natural assemblages of marine proteobacteria and members of the Cytophaga-Flavobacter cluster consuming low- and high-molecular-weight dissolved organic matter. Appl Environ Microbiol 66, 1692-1697.

Cowan, S. T. \& Steel, K. J. (1965). Manual for the Identification of Medical Bacteria. London: Cambridge University Press.

Felsenstein, J. (1993). PHYLIP (phylogenetic inference package), version 3.5c. Distributed by the author. Department of Genome Sciences, University of Washington, Seattle, USA.

Garrity, G. M. \& Holt, J. G. (2001). The road map to the Manual. In Bergey's Manual of Systematic Bacteriology, 2nd edn, vol. 1, pp. 119-166. Edited by D. R. Boone, R. W. Castenholz \& G. M. Garrity. New York: Springer.

Glöckner, F. O., Fuchs, B. M. \& Amann, R. (1999). Bacterioplankton composition of lakes and oceans: a first comparison based on fluorescence in situ hybridization. Appl Environ Microbiol 65, 3 721-3726.

Johnson, J. L. (1994). Similarity analysis of DNAs. In Methods for General and Molecular Bacteriology, pp. 656-682. Edited by P. Gerhardt, R. G. E. Murray, W. A. Wood \& N. R. Krieg. Washington, DC: American Society for Microbiology.

Jukes, T. H. \& Cantor, C. R. (1969). Evolution of protein molecules. In Mammalian Protein Metabolism, vol. 3, pp. 21-132. Edited by H. N. Munro. New York: Academic Press.

Kirchman, D. L. (2002). The ecology of Cytophaga-Flavobacteria in aquatic environments. FEMS Microbiol Ecol 39, 91-100.

Larkin, J. M. \& Borral, R. (1984). Genus II. Runella Larkin \& Williams $1978,35^{\mathrm{AL}}$. In Bergey's Manual of Systematic Bacteriology, vol. 1, pp. 128-129. Edited by N. R. Krieg \& J. G. Holt. Baltimore: Williams \& Wilkins.

Ludwig, W. \& Klenk, H.-P. (2001). Overview: a phylogenetic backbone and taxonomic framework for procaryotic systematics. In Bergey's Manual of Systematic Bacteriology, 2nd edn, vol. 1, pp. 49-66. Edited by D. R. Boone, R. W. Castenholz \& G. M. Garrity. New York: Springer.

Ludwig, W., Strunk, O., Klugbauer, S., Klugbauer, N., Weizenegger, M., Neumaier, J., Bachleitner, M. \& Schleifer, K.-H. (1998). Bacterial phylogeny based on comparative sequence analysis. Electrophoresis 19, 554-568.
McMahon, K. D., Dojka, M. A., Pace, N. R., Jenkins, D. \& Keasling, J. D. (2002). Polyphosphate kinase from activated sludge performing enhanced biological phosphorus removal. Appl Environ Microbiol 68, 4971-4978.

Murray, R. G. E., Doetsch, R. N. \& Robinow, C. F. (1994). Determinative and cytological light microscopy. In Methods for General and Molecular Bacteriology, pp. 21-41. Edited by P. Gerhardt, R. G. E. Murray, W. A. Wood \& N. R. Krieg. Washington, DC: American Society for Microbiology.

Nedashkovskaya, O. I., Suzuki, M., Vysotskii, M. V. \& Mikhailov, V. V. (2003). Reichenbachia agariperforans gen. nov., sp. nov., a novel marine bacterium in the phylum Cytophaga-Flavobacterium-Bacteroides. Int J Syst Evol Microbiol 53, 81-85.

Pandey, K. K., Mayilraj, S. \& Chakrabarti, T. (2002). Pseudomonas indica sp. nov., a novel butane-utilizing species. Int J Syst Evol Microbiol 52, 1559-1567.

Powers, E. M. (1995). Efficacy of the Ryu nonstaining $\mathrm{KOH}$ technique for rapidly determining Gram reactions of food-borne and waterborne bacteria and yeasts. Appl Environ Microbiol 61, 3756-3758.

Reddy, G. S. N. \& Garcia-Pichel, F. (2005). Dyadobacter crusticola sp. nov., from biological soil crusts in the Colorado Plateau, USA, and an emended description of the genus Dyadobacter Chelius and Triplett 2000. Int J Syst Evol Microbiol 55, 1295-1299.

Reichenbach, H. (1989). Genus I. Cytophaga Winogradsky 1929, $577^{\mathrm{AL}}$ emend. In Bergey's Manual of Systematic Bacteriology, vol. 3, pp. 2015-2050. Edited by N. R. Krieg \& J. G. Holt. Baltimore: Williams \& Wilkins.

Saha, P., Krishnamurthi, S., Mayilraj, S., Prasad, G. S., Bora, T. C. \& Chakrabarti, T. (2005). Aquimonas voraii gen. nov., sp. nov., a novel gammaproteobacterium isolated from a warm spring of Assam, India. Int J Syst Evol Microbiol 55, 1491-1495.

Saitou, N. \& Nei, M. (1987). The neighbor-joining method: a new method for reconstructing phylogenetic trees. Mol Biol Evol 4, 406-425.

Smibert, R. M. \& Krieg, N. R. (1994). Phenotypic characterization. In Methods for General and Molecular Bacteriology, pp. 607-654. Edited by P. Gerhardt, R. G. E. Murray, W. A. Wood \& N. R. Krieg. Washington, DC: American Society for Microbiology.

Thompson, J. D., Gibson, T. J., Plewniak, F., Jeanmougin, F. \& Higgins, D. G. (1997). The CLUSTAL_X windows interface: flexible strategies for multiple sequence alignment aided by quality analysis tools. Nucleic Acids Res 25, 4876-4882.

Van de Peer, Y. \& De Wachter, R. (1997). Construction of evolutionary distance trees with TREECON for Windows: accounting for variation in nucleotide substitution rate among sites. Comput Appl Biosci 13, 227-230.

Weon, H.-Y., Kim, B.-Y., Kwon, S.-W., Park, I. C., Cha, I. B., Tindall, B. J., Stackebrandt, E., Trüper, H.-G. \& Go, S. J. (2005). Leadbetterella byssophila gen. nov., sp. nov., isolated from cotton-waste composts for the cultivation of oyster mushroom. Int J Syst Evol Microbiol 55, 2297-2302.

Yoon, J.-H., Kang, S.-J., Lee, C.-H. \& Oh, T.-K. (2005). Marinicola seohaensis gen. nov., sp. nov., isolated from sea water of the Yellow Sea, Korea. Int J Syst Evol Microbiol 55, 859-863. 